\title{
Cautionary Tales: Making AND BReaking Community in the Oil Sands REGION $^{1}$
}

\author{
Clinton N. Westman
}

\begin{abstract}
I consider data from Cree and Métis history, ethnology, and mythology to focus on three transformative modes (integration, disintegration, and mediation) in relation to concepts of community. I develop an allegorical fantasy of oily monsters, tricksters, and their appetites arising from liquid commodities, in opposition to more integrative ritual practices that have historically underpinned community in the oil sands region of northern Alberta. Specifically, I suggest that (petro)-capitalism can be compared to the monstrous Windigo (not a trickster) with respect to its uncontrolled appetites and growth, and also that various proposed technical remediations resemble the vain adventures of the hubristic, foolish, and acquisitive Amerindian Trickster.
\end{abstract}

Keywords: oil sands; Aboriginal peoples; community; myth; ritual; petro-capitalism

Résumé: J'utilise des données de l'histoire des Cris et des Métis, de l'ethnologie et de la mythologie pour étudier trois modes de transformation (l'intégration, la désintégration et la médiation) se rapportant aux concepts de la communauté. Je développe une fantaisie allégorique de monstres du pétrole, de tricheurs et de leurs appétits émanant des produits liquides, contrairement à plusieurs pratiques rituelles d`intégration qui ont soutenu historiquement la communauté dans la région des sables bitumineux du Nord de l'Alberta. Plus précisément, je propose que le (pétro)-capitalisme peut être comparé au monstre Windigo en ce qui concerne ses appétits incontrôlables et sa croissance. De plus, je présume que plusieurs techniques de remédiation proposées ressemblent aux aventures vaines de l'hybris, stupide, et acquisitif Amérindien Tricheur (Trickster).

Mots clés: Les sables bitumineux ; les peuples autochtones ; la communauté ; le mythe ; le rituel ; le pétro-capitalisme

1. Acknowledgements: I would like to thank Dean Bavington, Mike Beaver, Reade Davis, Sara Dorow, Karen Hebert, Kota Kimura, Sara O'Shaughnessy, Richard J. Preston, Earle $\mathrm{H}$. Waugh, and two anonymous reviewers for their comments and suggestions on earlier drafts of this paper.

(C) Canadian Journal of Sociology/Cahiers canadiens de sociologie 38(2) 2013 


\section{INTRODUCTION}

In this paper, I set out examples and allegories from Aboriginal thought and history on phenomena and transformations that may be integrative, disintegrative, or complex and ambivalent in relation to community. Focusing on understanding how community is made and broken in the oil sands region of northern Alberta, I am interested in following an interpretive line in which oil sands developments are evaluated according to Aboriginal people's values of place and relatedness, based on the apprehension of a community including plants, animals, spirits, mythical beings, and the dead. Using diverse ethnographic data, I will suggest that development on the scale currently seen in the oil sands region cannot be meaningfully accommodated within such an Aboriginal cultural framework, in which community is understood as incorporating reciprocal relationships with humans and nonhumans, in a known and cared-for place.

I argue that it is necessary to consider a politics of community populations in the oil sands zone (as I do in Westman 2006; 2010; in press), but also to attend to the spiritual or conceptual aspects of community in this diverse region (as I do here). In order to understand how the region's Aboriginal inhabitants may define community and its correlates, I examine local histories, social organization, subsistence practices, redistributive ritual, ideologies around waste, selfish tricksters, and cold, slippery, monsters. I suggest that such local narratives and histories have much to teach us, and are good to think with. After providing some background on my theoretical perspective, methods, and context, I begin the main section of the paper, thinking through community and commodity in the bush, based on three transformational modes that become thematic for my paper: integration, disintegration, and mediation. Given the unstable nature of these transformations, my cautionary tales are fantastic as well as instructive.

\section{Oil, Community, and Fantasy}

It is critical to interrogate some of the many competing concepts of community evident in the culturally diverse oil sands region. As Gerald W. Creed (2006:4) states regarding community, "it is essential... to look inside this seemingly transparent term and discover the associations that are, as it were, hidden in plain view." Creed defines community as having a complex constitution including at least three component meanings: a group of people (note that, in many Aboriginal worldviews, persons are not necessarily restricted to living human beings), a quality of re- 
lationship (usually construed as positive), and a place/location. I try to understand how this complex system of concepts glosses onto Aboriginal worldviews, within the framework of the petro-capitalism that defines the oil sands region of northern Alberta.

In the same volume, Michael Watts reminds us that oil nations or petro-states stand in relation to a particularly fantastic sort of capitalism (petro-capitalism), with special implications for community, through which "a key resource (oil) and a logic of extraction figure centrally in the making and breaking of community" (2006:105). Watts contends that petro-capitalism operates by using "spectacle and illusion" (2006:115), thereby distorting previous social and economic organization through an "oil complex" that "constitutes a radical — and multifaceted challenge" to "systems of ethnic identity" (2006:106), such as modes of relatedness. In the Aboriginal communities of northern Alberta, oil has been and remains a pivotal factor in breaking down communities of humans and nonhumans as traditionally conceived, and replacing them with a community that is unequal, atomistic, more disconnected from its environment, and largely dependent or lumpenized.

My cautionary tales are crosscultural allegories and critical interpretations of petro-capitalism, which, like a "genie," fulfills fantasies and erases memories, resulting in unequal, undemocratic, and nontransparent "petro-politics" (Nikiforuk 2010:171). Petro-capitalism is "a capitalism that hinges on the production, exchange, and consumption of petroleum" (Valdivia 2010). Petro-capitalism is thus central to contemporary global society, and petroleum is its basic unit or commodity. Petro-politics and petro-capitalism can be seen in situations where oil is conflated with the public interest, resulting in a distorted, imbalanced, political economy, in which other visions of community are devalued. As the world's largest single energy project, the oil sands are particularly and specifically implicated in this schema.

My intent is not to compare or contrast Aboriginal understandings and practices with the existing practical ideology of petro-politics, or to outline the objective characteristics of petro-capitalism. Rather, I imagine how current oil sands practices and proposals - focusing on continuous growth, acquisition, and waste - might appear from within an Aboriginal worldview informed by specific stories, ceremonies, and histories.

While the word community is mentioned repeatedly in official oil sands discourse (e.g., industry and government reports) in relation to Aboriginal people, it usually refers to political or geographic entities, rather than correlates such as landscape, social organization, past or future people, nonhuman sentient beings, and spiritual connections. Yet all 
these, I assert, are pivotal in understanding the community that constitutes the lifeworld of Aboriginal people in the oil sands region. What are the qualities, then (to come back to Creed), of the relationships that Cree, Métis, and Dene may have with human and nonhuman entities in the boreal forest? How can such qualities be enhanced or integrated within contemporary life? What sorts of remediations, schemes, and tricks are suitable to maintain them in the face of environmental change? And what can these qualities or concepts teach us about the monstrous part of ourselves, which threatens to tear down or disintegrate community and its basis in nature? It is these Aboriginal conceptions of transformation of community - integration, mediation, and disintegration - that interest me in my discussion of how community is conceived, valued, made, and broken. I am especially concerned with how such insights are represented by Aboriginal people themselves (King 2003), and how such interpretive understandings of community might be applied to contemporary socioecological problems (Cruikshank 2005).

\section{Methodology}

I apply a wide range of ethnographic methods to understand problems related to environment, religion, history, and culture in northern Alberta. The insights I develop in this article are based on long-term fieldwork in Cree-Métis communities and with archival collections, as well as on secondary reading of ethnological comparators. Specifically, since 1996 I have conducted ethnographic fieldwork, environmental assessment, land claims research, and community consultations in and around several northern Alberta communities, especially Peerless Lake, Cadotte Lake, and Trout Lake. These communities are located north of Lesser Slave Lake, between the Peace and Athabasca rivers, and also amidst the two largest oil sands deposits in Alberta (the Peace River and Athabasca deposits). Home to both Cree and Métis people, each of these communities has fewer than 1000 inhabitants. The Cree language is in daily use in many if not most households, with wild meat and fish constituting important food sources. For my research, I have studied intensively the Cree language and its spiritual concepts, and attended traditional Cree rituals, including several of the wîhkôhtowin ceremonies described in this article. I have also examined the legally mandated impact assessment studies on proposed oil sands projects, particularly aspects relating to proposed projects' projected impacts on traditional land use (including subsistence-oriented and spiritually oriented land uses) of Aboriginal people (Westman 2006; in press). 
In particular, I have witnessed the complex dance - played out at meetings and through documents - whereby industry and government representatives present oil sands development as inevitable, beneficial, and harmless. The flat and sometimes glib technical arguments used by such spokespeople have contrasted strongly with the emotional, experiential, and finally resigned petitions of hunters, trappers, gatherers, fishers, and elders (Westman 2006; in press). These hunters and bureaucrats were largely talking past one another, without sharing a common worldview (Nadasdy 2003). Thus, proposals to benefit the community through development have fallen short owing to the lack of a shared definition of community.

\section{The Alberta Oil Sands and Aboriginal People}

For thousands of years, Aboriginal people have lived on the lands above the Peace River, Athabasca, and Cold Lake oil sands deposits, sometimes using the surface tar along the Athabasca River as part of their seasonal rounds (famously, to pitch their bark canoes), and showing it to 18th century European explorers, who immediately recognized the economic potential of what they called bituminous fountains. Such potential remained unrealized until the mid 20th century, by which time First Nations people in the region had signed Treaties Six, Eight, and Ten. The written texts of these treaties commute most land rights to the Crown, while guaranteeing First Nations a livelihood based on hunting and trapping, subject to the government "taking up" land from time to time for purposes such as mining. The Aboriginal oral traditions around such treaties see them as agreements to share the land - perhaps only the surface of the land - with First Nations people generally retaining considerable autonomy over their lives and territories (Cardinal and Hildebrandt 2000). These competing visions are the subject of negotiation and litigation, as are the complex and developing hunting and governance rights of Métis people (who did not sign treaty or receive hunting rights, but who in many cases, and through a tainted process, accepted scrip to extinguish their rights). Central to both First Nations and Métis concerns in the communities where I studied is the question of how to exercise hunting and sovereignty rights - emblematic of identity politics and a larger partnership with nature.

Aboriginal people have not simply used lands, waters, plants, and animals in an instrumental fashion, but rather have entered into relations with spirits connected with plants, animals, and places. Subarctic religions were and are largely nature-based, according the status of person 
to animals, plants, and potentially rocks. To kill and eat meant participating in a gift-specified relationship that was sacralized by ritual and sanctioned by taboo. Hunting, trapping, fishing, gathering, and eating continue today as means of manifesting such spiritualities and identities. When questioned about how they value lands for which oil sands development is proposed, Aboriginal people frequently speak about the people who lived there in the past, the presence of graves, old ceremonial sites, cabins, and a sense of quiet. They talk in a way that also speaks to spiritual, contemplative, and relational concerns. This air of contemplation and sacralization in nature is threatened by a resource boom that is rapidly gobbling up lands and waters. Numerous technical studies refer to the scope and scale of oil sands impacts on Aboriginal people (e.g., Candler et al. 2010), as do public comments and statements of claim from First Nations leaders who have commenced litigation on this issue (e.g., Droitsch and Simieritsch 2010).

The oil sands are deposits of bitumen containing the equivalent of trillions of barrels of oil in a mixture of sand, water, and clay. Typically exploited by open pit mines with tailings ponds covering a vast area, other approaches used more recently for unmineable oil sands deposits (mainly outside the Athabasca River corridor) include in situ processes, which make use of heating, pumping, and pipeline networks to liquefy and extract underground bitumen beneath expanses of boreal forest that become scarred with linear disturbances. The extraction processes are complex and costly, involving the separation of bitumen using heat, chemicals, and water.

Oil sands are less sustainable than conventional fuel sources because their impacts are both extensive and intensive in nature; oil sands extraction and refining are relatively energy- and water-intensive. The sector is not only growing rapidly, but each project radically alters a large area; land reclamation efforts to date are miniscule for this 50-year-old industry. Several recent scientific reports have concluded that the oil sands industry is polluting air, land, and water to an extent that may be harmful to the health of animals, plants, and humans, particularly those who consume bush foods (e.g., Kelly et al. 2010). Further research is ongoing in these areas, yet development continues apace. This tendency to conduct research after projects have already gone ahead is surely one of the most pernicious fantasies wrought by the sorcerer, petro-capitalism, and its genie, petro-politics.

My observations pertain most directly to small communities in central northern Alberta (Trout Lake, Peerless Lake, and Cadotte Lake) that officially sit outside of the Regional Municipality of Wood Buffalo (RMWB) and the mineable deposits, away from the media and hustle of 
Fort McMurray. Yet they are still within the oil sands zone and still face rampant development. Isolated communities in north-central Alberta are currently affected by various in situ developments, such as Shell's Peace River project. In the vicinity of the Shell plant, an established (and expanding) in situ upgrading complex northeast of the town of Peace River, local people note that wildlife such as moose have largely disappeared from the vicinity of the site, formerly an important hunting and cultural area. There are also many smaller in situ projects ongoing to the east of this region, on the western fringe of the Athabasca deposits, including those of the Sunshine, Devon, and Laracina energy corporations. Further intensive development and more exploration of oil sands and other resources in the unmineable region on the fringe of the Athabasca oil sands zone (around Trout Lake and Peerless Lake) are currently proposed by many companies.

One such project, currently under development, is Devon Energy's "cold flow" in situ proposal that will make use of a widespread pumping and pipeline infrastructure with hundreds of drill holes, including batteries of large tanks at ground level that will contain bitumen kept permanently just below boiling point, to off-gas and thin out the small proportion of heavy, viscous oil that could be retrieved by drilling. As of 2011, no vapour recovery was proposed for this off-gassing process; although vapour recovery technology existed, the company considered it uneconomical. This Devon plan will use water from Peerless Lake, a major fishing lake with sport as well as subsistence fisheries, which provides drinking water for regional communities. Shell's massive Grosmont play is another, highly technical and somewhat secretive, if rather phallic, in situ proposal calling for the insertion of large electric heaters in the earth, to slowly "move" over time through the woods in a wide swath, obliterating pristine wilderness traplines with roads, powerlines, and pumping/pipeline infrastructure. The health and environmental implications of such proposals are likely to be significant, even when compared to the more widely known mining and tailings pond infrastructure seen in the Athabasca deposit that lies mostly within the RMWB. Indeed, hunters and trappers throughout the region note damage to fish, berries, wildlife, and other resources wherever oil sands developments have occurred. Such processes have negative impacts on community as conceived and lived by the Aboriginal people in the area.

The pace and scale of oil sands investments, the dearth of baseline studies or knowledge about potential impacts, the waste inherent in production of this dirty fuel, and the shift in political discourse towards a representation of oil sands as being Canada's and Alberta's paramount political economic interest and "sustainable energy" calling card, point 
to a short-term thinking that is certainly foolish (in the manner of the Trickster?), but which also has its own monstrous logic (in the manner of the Windigo?). According to this logic, the oil sands' synthetic crude is required as the sine qua non of our consumptive economy, becoming, like money, a kind of master commodity: a highly liquid symbol of transformation and possibility. Since oil (particularly in its "heavy" or bituminous manifestations) is both liquid and solid, poison and boon, material and symbolic, an interpretive analysis based in magic realism and transformation seems appropriate.

\section{Thinking through Community and Commodity in the Bush}

The various forms of transformation that can affect community are important in understanding mythology and knowledge of Amerindians, as Claude Lévi-Strauss $(1966$; 1971) emphasized in his work. Some transformations involve oppositional forces of disintegration that threaten to destroy or diminish community; others are integrative processes and events that support or even define community for their participants. Still other forms of mediation and remediation are more ambiguous, with potential to affect community in both destructive and creative ways, or to entail still other transformations. Accordingly, I have taken the concepts of disintegration, integration, and mediation as the organizing ideas for this section on thinking through community in central northern Alberta.

Under the rubric of integration, I consider ethnographic data on rituals, pointing towards the ideal notions and practices constituting community for the Aboriginal people in the region with whom I conducted my fieldwork. Under the rubric of disintegration, I consider the monstrous Windigo traits of waste, appetite, and mindless destruction; I document the intensification of the Windigo logic of capitalism, commodity fetishism, and the impacts of oil sands development on community as felt, lived, and conceptualized by Aboriginal people in northern Alberta. Under the rubric of mediation, I consider the Trickster myths cautionary but not exemplary tales of an ambivalent primordial person who is neither human nor animal, neither good nor evil - in comparison to various technical remediations proposed in the oil sands sector today. Note that the Windigo (a predator of humans with rapid growth and a distorted perspective) and the Trickster (a more ambivalent figure with creative and cultural potentiality) are not synonymous. In spite of a shared tendency towards mindless greed, the nature of these protagonists and their narratives are quite different, although both can be seen in opposition to the integrative rituals and practices I discuss below. 
Nevertheless, each of these three modes of transforming community has something to show us about the impact and meaning of an age of petrocapitalism and environmental crisis.

\section{Integration}

Subarctic band societies were (and, to some extent, still are) based on the principles of sharing and reciprocity in a very concrete way. This is the essence of community identity and also of enlightened self-interest. Not to share what one has is not to be a member of the community. Not to share invites death by starvation. In anthropological terms, because of their high ability to meet needs through sharing and their low level of wants, members of such mobile, flexible, co-operative groups have been considered "affluent" (Sahlins 1972:1) by some. Other anthropologists, using more overtly Marxist approaches, have argued that the subarctic hunting band's political economy resembled that of "primitive communism" (Engels 1972; cf. Leacock 1982:162) due to the absence of private ownership over land, people, and animals. In either case, as the lack of want, affluence derives from the absence of the commodity. Relations with objects and with nature, as well as with people, are social and spiritual more than instrumental. Marshall Sahlins famously suggested that many such values have survived into the present as a form of indigenized modernity (1999:viii).

In congruence with an indigenized version of modernity, complete with its own conceptions of affluence, northern Alberta Métis researcher Elmer Ghostkeeper (1996) describes his own spiritual revitalization towards a way of life characterized by "spirit gifting" among a broad community including animals, plants, and ancestors. Ghostkeeper sets out the principles of relatedness and community by examining a northern Alberta Métis seasonal round, its subsistence practices, and its ceremonies during his youth in the early 1960s. He then contrasts this with his later work as an oilfield contractor. Ghostkeeper's work captures the conflict that many subarctic Aboriginal people may feel about development, its transformative benefits, and its impacts on community. He both calls for, and attests to, a continued revitalization of Aboriginal traditions and reenactment of Aboriginal practices connoting community with spirits, ancestors, land, and animals.

My research suggests that one particular ceremony, the wîhkôhtowin, is especially significant in enacting Cree and Métis values connoting community and spirit gifting, in both the eastern and western regions of the oil sands zone. The wîkôhtowin is a redistributive ritual complex combining features of dancing, feasting, sacrifice, singing, drumming, 
praying, gifting, visiting, and healing. Traditionally it was undertaken in spring and fall (and also perhaps at mid-summer), at important seasonal gathering sites. As such it was a major feature of Western Woods Cree social life, building solidarity among micro-bands throughout the season of their largest gatherings. It continues to serve an integrative function by honouring relations to living people, ancestors, and the spirit world, and also by sacralizing items of personal power, such as medicine bundles, and bringing them into the rhythm of the seasons and of plant life. Bundles are elevated in a most sacred part of the lodge. A bundle carrier, or "someone who knows something," puts the ceremony on, while teaching younger apprentices who will someday do the same.

The ceremony consists of dancing, in a clockwise direction and in single file, around four fires. The fires burn within an elongated lodge constructed from three conical teepee frames, partially covered with canvass or boughs but open across the top. The fires are tended by young men, who also distribute the tea, cigarettes, food, and gifts stored amongst the fires. People sit around the lodge's edge, leaving open a trail for dancing clockwise around the fires. Opposite the entry sit the singers and drummers; they take turns singing songs learned in dreams or from ancestors, over four rounds of singing, dancing, smoking, and feasting. The lodge symbolically brings the entire community together for a feast, which is shared, and which also feeds others who are not physically present while honouring plants, animals, spirits, and the dead. It is forbidden to waste the food that is shared.

The work of Cree artist and scholar Dale Auger (e.g., 2006), apparently drawing on myths of the ritual's origin, suggests that the wîkkôhtowin was a gift to the people from the Loon, whom people had helped previously. The Loon returned a favour by restoring spiritual power and the ability to provide to a young man, who had angered the spirits through his greed and selfishness. The ceremony commemorates this integral relationship with the world of spirits, plants, and animals, and the ability of humble humans to come back into accord with this community.

To come back to Creed's comments about the need to interrogate community as a seemingly self-explanatory term, it is critical that we be open to such ideas of community and reciprocity, even out in the bush when no one is around. In Aboriginal myths and rituals, sentient beings are always present to watch, guide, assist, or withhold. Such conceptions of community simply are not viewed as serious or important within the political, consultation, and impact assessment processes governing oil sands development, wherein discussions of ceremonies, spirituality, and the sacred are largely sidelined or ignored in favour of technical concerns (Westman 2006:38). 


\section{Disintegration}

In setting out a monstrous vision of what may happen when abundance is not shared, when human and nonhuman persons are not respected, and when plants and animals are wasted or defiled, I turn to the concept of the Windigo. The Windigo is a relatively well-known personage from Cree mythology (present in Dene thought as Wechuge), typically conceived as a former human being who has turned into an anthropophagous monster through greed (paradigmatically, cannibalism). The Windigo also provides a means to understand various aspects of modernity within a Cree worldview. In looking at modern monsters, I am inspired by Michael T. Taussig (1980), Fernando Coronil (1997), and Mary Weismantel (2001), among others. These three anthropologists point out that the monsters, sorcerers, and devils of Indigenous and other non-Western subjects are often fantastic refractions of existing and historical capitalist relations. More broadly, this suggests that the history of capitalism - perhaps particularly late capitalism - can be told as a monster story, as Annalee Newitz does in Pretend We're Dead: Capitalist Monsters in American Pop Culture (2006), or as David McNally does in Monsters of the Market: Zombies, Vampires, and Global Capitalism (2011). It is in this spirit that I offer my analysis of disintegration of community; by looking at beliefs about the opposite of community, we may come to understand how it is made and broken in a particular place.

I suggest that the logic of petro-capitalist extraction resembles the predatory logic of the Windigo, a dangerous (and rapidly growing) entity that has lost its humanity and proper sense of relatedness to others. This resembles the analysis in the Achbar et al. (2003) film, The Corporation, which considered the fictive corporate person as conforming to the typical attachment and behaviour patterns of a psychopath. The distorted perspective of the fictive corporate person resembles the distorted perspective of the Windigo (cf. Brightman 2002), and so the abhorrent becomes logical.

As Watts (2006), Coronil (1997), and others have written, it may be that oil as a commodity, or petro-capitalism as a system, is especially suited to promoting monstrous, fantastic, or psychopathic imaginings, particularly in peripheral regions where neocolonial relations of inequality prevail. For example, Ken Saro-Wiwa wrote that oil had contributed to turning Nigeria into a "vampire-like" state, sucking the life out of nature and humans in Ogoniland through pipelines and pumping stations (quoted in Apter 2005:267). Andrew Apter explores the close linkages of Saro-Wiwa's comment to traditional Yoruba notions of blood-sucking monsters, as translated into a commodity world of violence and insecur- 
ity (Apter 2005:267). Such an approach to oily monsters and visions, then, is part of the framework for my discussion of community in the oil sands region.

The magical transformation of a person, state, or a company into a monster resembles another fantastic transformation of relations, suggested in the Marxian concept of commodity fetishism (McNally 2011:123-126; Taussig 1980). The role of the commodity in effecting a change in human relations with nature and with objects is of critical concern in Marxist thought (Harvey 2010; Marx 1988), and also is of interest to subarctic Aboriginal people, who revere and remember elders and ancestors who lived on the land full time prior to the advent of capitalist relations and the arrival of western goods (Vincent 1991). This shift from affluence to commoditization devalues community and connection with people and things, promoting the Windigo traits of desire, greed, and hunger, predicated on unnatural growth and acquisitiveness.

I am attempting to establish that there is a relationship between the Windigo and capitalism. It is events of the long 20th century (1890spresent) - in this case, most closely associated with the intensification of capitalist relations in northern Alberta - that are today most strongly associated with trauma and transformation. To understand the oil sands' impact on community, I look backwards at previous transformations in the region. In effect, the transition to capitalism, sedentary communities, oil, and underdevelopment is strongly associated with the commoditization of social life and the appearance of social pathologies. Money was almost unheard of in most parts of northern Alberta prior to 1900, and continued to be relatively insignificant in many locales for several decades thereafter. Yet it seems to have been the introduction of money (like oil, a master commodity) that coincided with a series of crises including ill health, increased alcohol consumption, and windigo manifestations.

For example, in the years around 1900, when Treaty 8 was signed, and as missionaries, police, and money began to appear in the most isolated districts of northern Alberta, many people claimed that they were becoming windigos (Carlson 2009; Leonard 2000:102). The bestdocumented case of a windigo manifestation occurred in Trout Lake in 1896 (Carlson 2009; Westman 2008), when a man spoke of the ice rising in his innards, and warned his relatives to kill him before he turned on them in his hunger.

Windigo is conceptually linked to cannibalism, waste, hunger, greed, and the idea of pâstâhôwin: antagonizing spirit beings to invite vengeance. Robert Brightman (2002) has shown how the Windigo phenomenon is thus inversely integrated into an overall Cree ideology about hunting, eating, and correct relations between people and animals: that 
is, Windigo conceptually relates to and results from breaches of the good life, or of appropriate means of subsistence, as insults to the fabric of community. While the concept of the Windigo has a rich analytical history (Waldram 2004), I would like to draw attention here to a stream of thought in which the Windigo is seen as representing by analogy the more negative aspects of modern social life - those that are most harmful to community.

In particular, a strong conceptual link exists between the Windigo and contemporary Aboriginal thinking on suicide (McKinley 2011). Suicide is historically linked to the entrenchment of capitalism, dependency, sedentarization, and oil in the communities I study. So an understanding of the Windigo is pivotal to an Aboriginal understanding of how oil breaks communities in its wake. Thus, while the windigos may have gone underground after their outbreak in the early 20th Century, their handiwork can still be seen in these subsequent developments.

Notwithstanding the slow growth of the presence of state and church, by and large - at least in the central region of northern Alberta - Aboriginal people remained semi-nomadic and generally self-reliant into the 1950s and 1960s, when most settled in permanent communities, albeit with poor transportation, communication, and services. It is also this period that saw the beginnings of large-scale oil exploration and extraction in the region. Around Trout Lake, Peerless Lake, and Cadotte Lake, the arrival of oil roads and oil companies around most regional communities in the 1960s-1970s brought the next, more rapid, intensification of capitalist economic relations, missionaries, and state institutions including welfare payments (Westman 2008; 2010). Here, too, we see traces of the Windigo, as archival records from Trout Lake in the late 1960s allow an early glimpse of the pattern of suicide, "accidents," violence, political client status, and dependency that can be seen in the region today (Westman 2008; 2010).

This social unraveling can be partly attributed to the decline of subsistence practices accompanying sedentarization and industrialization, and to the decline of the web of interconnectedness and responsibility that these subsistence practices implied. I surmise that social problems may continue to be thought of in monstrous or Windigo-inspired terms, as industry rapidly moves into new areas and intensifies its existing developments. No doubt such expansions will affect hunting and trapping, fishing and gathering, while making it harder for local people to find the peace and quiet they crave as they go about making a portion of their livelihood from nature. This livelihood entails a broader sense of community and place, which is also vulnerable. Returning to fantasy, one trapper described the rapid intensification of oil and gas developments 
on his trapline, since the dogsled days of the early seventies, as being "like a dream." He was referring to the sense of unreality and rapidity in the change, but perhaps also to a nightmarish quality.

Given the fantastic nature and unrelenting growth of the projects I have described above, I see petro-capitalism allegorically as having disintegrative Windigo-like characteristics, due to its potential to scatter, endanger, and destroy communities, in the senses of physical dwellings, known places, collectivities of persons, and broader networks of relatedness. We have also seen how some episodes in regional history can be interpreted through the lens of the Windigo stories. An underlying logic is pivotal to such processes, in which the identity and community of victims are radically devalued according to an acquisitive logic in which they are not really heard. To extend my argument further, I would suggest that we, as human beings, are putting ourselves in danger by forgetting what we know about community and relatedness, and by accepting this deeply distorted, sociopathic, corporate logic of growth and consumption as common sense.

\section{(Re)mediation}

Now I turn from horror to comedy (or, as Marx writes, from tragedy to farce). Here I evaluate specific technical mediations and remediations (primarily proposals and practices regarding wastewater disposal and carbon sequestration), contrasting these with Aboriginal perspectives on what happens to those who will not control their appetites or their waste. To do so I will tell another (Trickster) story, but one which does not imply the truth or falsehood of the Windigo connection. This is, rather, another alternative reading of what given practices and proposals in the oil sands might mean in relation to Aboriginal concepts that touch on the notions of community and of personal responsibility.

Practices evident in oil sands production and promotion - particularly those involving technical remediations intended to solve perceived environmental problems while continuing to produce large amounts of petroleum - resemble those of the Trickster, an ambivalent figure familiar in mythology, especially as described by Paul Radin (1975), perhaps the foremost anthropological expert on the Amerindian Trickster. Due to lack of self-knowledge and inability to control his appetites, the Trickster (who for the Cree resembles his namesake, the voracious Grey Jaybird) deceives humans and animals, but frequently cannot avoid the consequences of his actions. The Trickster's adventures are earthy indeed, sometimes involving his disobedient anus and enormous penis, which can take on a will of their own. It is easy to imagine the Trickster's sexual 
and culinary adventures (as well as their sometimes unpleasant consequences) in relation to the oil sands projects I have mentioned above, as gigantic devices penetrate the earth, and water and land are devoured whilst foul waste belches out in their place.

In one case, the Trickster is deceived into eating a talking laxative plant, which tauntingly warns him of the consequences in store for him. The results are predictable, as he passes wind to such an extent that his life is threatened. In the process the Trickster nearly destroys nascent human society by scattering the primordial community of humans, their tent, and possessions, across the landscape. Subsequently he begins to defecate: so much so that he nearly drowns in his own filth, practically losing his detachable penis in the process. Blinded by feces, he is taunted and harassed by trees until he stumbles into the water and cleanses himself (Radin 1975:25-28). In a Western Woods Cree version of the story told by Louis Bird (2007:190), the Trickster farts so much he cannot catch food and begins to starve. This, too, connotes social breakdown: greed that destroys not only the community between people and animals, but threatens the human community itself. To paraphrase Robert Brightman's discussion of this mythic cycle (2007:40), perhaps the Trickster's acquisitive adventures and their explosive consequences have nothing to do with the ideology and practices of contemporary oil sands extraction and associated remediation proposals, or even with an implicit critique of modernity. But I doubt it.

I suggest that water management - currently perhaps the single largest acknowledged technical and environmental problem facing oil sands proponents in both the mineable and nonmineable zones - can be viewed through the lens of the Trickster myth cycle. We can see similarities in the use of surface water (for instance from Peerless Lake) and ground water, as this vital component of ecosystems and of community is used as a component of production, to heat, fracture, pressurize, and refine, or simply to absorb waste runoff, thus affecting both water quantity (Candler et al. 2010) and water quality (Kelly et al. 2010, Schindler 2010, Timoney and Lee 2009) throughout the oil sands region. While highly visible in tailings ponds seen around the mineable deposits, toxic wastewater is generally pumped underground in the in situ projects of the central, southern, and western regions of the oil sands zone. The long-term impacts of these terrestrial and subterranean liquid wastes on potable water sources and on the ambient environment are unclear. In either case, water, transformed as steam, loses its own liquidity and purity to allow the oil (sands) to flow with an impure liquidity. Like this perhaps infelicitous transformation, the myth I recounted immediately 
above begins with consumption largely for the sake of vanity, and so is relevant to philosophical discussions of the commodity form, as well.

Moving away from the study communities briefly to consider the Trickster myths' lessons for the broader climate and environmental debates, one can also see an analogy to the carbon economy and to climate change in this mythic cycle. A supposedly painless solution to oil sands $\mathrm{CO}_{2}$ emissions (only one component of airborne emissions) that has been proposed is that of Carbon Capturing and Sequestration (CCS), whereby carbon emissions are captured and pumped underground. Extending my discussion of Trickster and his bodily waste slightly further, CCS proposals have always called to my mind another widespread motif in Amerindian mythology: that of the anal stopper. As described by Claude Lévi-Strauss (1971:386-387), this myth is another involving defecation, in which the Trickster is forced to plug his anus with plant matter in order to retain food. While I would not wish to overextend this particularly grotesque analogy, perhaps it is a good corrective to the solemn tones in which CCS is being discussed by governments and corporations as a serious climate solution. My analogies of CCS and wastewater management techniques to an anal stopper, and of liquid tailings (or airborne emissions) to a huge bowel movement (or a major fart), also tend to support Lévi-Strauss' (1966) earlier assertions suggesting the fantastic character of many scientific interventions, as well as the explanatory and scientific value of mythological accounts (cf. Nader 2010). These remediation processes affect my study communities as members of the human community, but also in the sense that they reframe the broader debate whereby oil sands developments on their territory are legitimized and rendered "sustainable."

These Trickster myths are both funny and frightening. They cut to the heart of discussions about community by showing how one tricky stratum of society can - through actions that may initially seem more ridiculous than scary - nevertheless create a big mess that makes it hard for people to live in community in or with a given location (the scale is variable, from Fort McKay to Planet Earth). It is fitting that the Trickster is creative as well as destructive, since the same is true of petrocapitalism, its baubles, and its benefits. The challenge is to learn from the myths. Even the Trickster can learn a lesson eventually. Hopefully we can do the same before we get in deep shit.

\section{Practical Magic?}

The Windigo (again, not a trickster) and Trickster stories are different interpretations - and to some extent both complementary and alter- 
narratives - of what can happen to wasteful and greedy people who do not consider the impacts of their desires, and to the communities such people inhabit. These myths may be seen - apart from their etiological and other functional characteristics - as different inversions of the ideal of community set out in the practices of Spirit Gifting, such as the wîhkôhtowin ritual. These myths and rituals, practically and conceptually, provide both models of and models for community life (Geertz 1973:93).

One shared question of these rituals, myths, technical problems, transformations, and conflicts is how to produce energy or sustenance while avoiding excessive waste, waste that is harmful to a wider community of others. Waste is a key concern in Cree relations with nature, as exemplified by practices such as the wîhkôhtowin (sometimes translated as the "Eat-All Feast" [Brightman 2002]) and the elevation of animal remains, which emphasize that to throw away precious parts, or waste meat, offends the animal (Tanner 1979; Brightman 2002). According to Louis Bird, this type of sin against nature - pâstâhôwin - is akin to abusing a family member, and calls for vengeance from the cosmos. The inverse of wasting - greedily hoarding or mindlessly consuming - has similar connotations. Such insights are highly relevant to discussions of both energy extraction and commodity fetishism in northern Alberta and elsewhere.

\section{Conclusion}

I assert that my cautionary tales are relevant to the broader community of persons on Earth. Integrating concepts of community at the highest level, recall that the wîkkôhtowin lodge is open to, and symbolically contains, all the members of a community, either physically or spiritually. I would like to suggest that all humans, on some level, are participating in a similar reciprocal process with the larger world, sharing in a common bounty while facing common threats, threats such as the allegorical inversions of community that I described in the Windigo and Trickster myths and histories.

My tales are linked not only to local myths, rituals, and histories of Amerindians in Alberta and beyond, but to a global academic literature (Apter 2005; Coronil 1997, McNally 2011; Newitz 2006; Taussig 1980; Watts 2006; Weismantel 2001) and a global current of popular thought (documented ethnographically in the literature mentioned above), which suggest that capitalism (perhaps especially petro-capitalism) has monstrous, sociopathic characteristics. Furthermore, narrow technical solu- 
tions or remediations, which do not draw on a political-ecological critique of overall policies and processes oriented to the rights of future humans and nonhumans, can be seen as foolish, even ridiculous, in attempting to hold back the consequences of wasteful consumption. Analytical approaches drawing on imaginaries, magic, myths, monsters, primordial urges, and strange happenings help us question the Western narrative about the supremacy of scientific knowledge and just-in-time technical solutions, and so have much to contribute to a political-ecological critique of environmental crisis. Such approaches also point to the limits of existing Western/capitalist concepts of community, rights, and duties. As components of Aboriginal knowledge, mythical understandings and ritual practices may point to some of the frailties in shortsighted, anthropocentric (and perhaps petro-centric) understandings of the world and of community. It is only by reflecting on such understandings, histories, and practices, on how they constitute or invert local notions of relatedness and, correspondingly, by recognizing many state and corporate claims and proposals as potentially either monstrous or foolish — that one can come to a full understanding of the dynamics of community as currently enacted in the oil sands region.

\section{REFERENCES}

Achbar, Mark, Jennifer Abbott, and Joel Bakan. 2003. The Corporation. Big Picture Media Corporation and Zeitgeist Films.

Apter, Andrew. 2005. The Pan-African Nation: Oil and the Spectacle of Culture in Nigeria. Chicago: University of Chicago Press.

Auger, Dale. 2006. Mwâkwa Talks to the Loon: A Cree Story for Children. Aboriginal Education Collection. Surrey, BC: Heritage House.

Bird, Louis. 2007. The Spirit Lives in the Mind: Omushkego Stories, Lives, and Dreams, compiled and edited by Susan Elaine Gray. Montreal: McGillQueen's University Press.

Brightman, Robert. 2002. Grateful Prey: Rock Cree Human-Animal Relationships. Regina: Canadian Plains Research Centre.

2007. Nature and culture in the bush: A nature/culture metalanguage and Rock Cree parallels. Pp. 31-44 in Frédéric B. Laugrand and Jarich G. Oosten, eds., La nature des esprits dans les cosmologies autochtones/ Nature of Spirits in Aboriginal Cosmologies. Québec: Les Presses de l'Université Laval.

Candler, Craig, Rachel Olson, Steven DeRoy, and the Firelight Group Research Cooperative, with the Athabasca Chipewyan First Nation and the Mikisew Cree First Nation. 2010. As Long as the Rivers Flow: Athabasca River Knowledge, Use and Change. Edmonton: Parkland Institute. 
Cardinal, Harold and Walter Hildebrandt. 2000. Treaty Elders of Saskatchewan: Our Dream is that Our Peoples will One Day be Clearly Recognized as Nations. Calgary: University of Calgary Press.

Carlson, Nathan D. 2009. Reviving Witiko (Windigo): An ethnohistory of "cannibal monsters" in the Athabasca district of northern Alberta, 1878-1910. Ethnohistory 56(3):355-394.

Coronil, Fernando. 1997. The Magical State: Nature, Money, and Modernity in Venezuela. Chicago: The University of Chicago Press.

Creed, Gerald W. 2006. Reconsidering community. Pp. 3-22 in Gerald W. Creed, ed., The Seductions of Community. Santa Fe, NM: School of American Research Press.

Cruikshank, Julie. 2005. Do Glaciers Listen? Local Knowledge, Colonial Encounters, and Social Imagination. Vancouver: UBC Press.

Droitsch, Danielle and Terra Simieritsch. 2010. Canadian Aboriginal Concerns with Oilsands: A Compilation of Key Issues, Resolutions and Legal Activities. Edmonton: Pembina Institute and Oilsands Watch.

Engels, Friedrich. 1972. The Origin of the Family, Private Property and the State: In the Light of the Researches of Lewis H. Morgan. New York: International Publishers.

Geertz, Clifford. 1973. The Interpretation of Cultures: Selected Essays. New York: Basic Books.

Ghostkeeper, Elmer. 1996. Spirit Gifting: The Concept of Spiritual Exchange. Calgary: Arctic Institute of North America.

Harvey, David. 2010. A Companion to Marx's Capital. London: Verso.

Kelly, Erin N., Jeffrey W. Short, David W. Schindler, Peter V. Hodson, Mingsheng Ma, Alvin K. Kwan, and Barbra L. Fortin. 2010. Oil Sands Development Contributes Polycyclic Aromatic Compounds to the Athabasca River and its Tributaries. Proceedings of the National Academy of Sciences 106.52:22346-22351.

King, Thomas. 2003. The Truth About Stories: A Native Narrative. Toronto: House of Anansi Press.

Leacock, Eleanor. 1982. Relations of production in band society. Pp. 159-170 in Eleanor Leacock and Richard Lee, eds., Politics and History in Band Societies. Cambridge: Cambridge University Press.

Lévi-Strauss, Claude. 1966. The Savage Mind. Chicago: University of Chicago Press.

1971. The Naked Man, Introduction to a Science of Mythology: 4. New York: Harper and Row.

Leonard, David W. 2000. Delayed Frontier: The Peace River Country to 1909. Calgary, AB: Detselig Enterprises Ltd. 
Marx, Karl. 1988. Selected Writings, edited by David McLellan. Oxford: Oxford University Press.

McKinley, Gerald. 2011. Representing Death: Suicide, Windigo and Intersubjectivity in Contemporary Indigenous Literature. $43^{\text {rd }}$ Algonquian Conference, University of Michigan, Ann Arbor, MI.

McNally, David. 2011. Monsters of the Market: Zombies, Vampires, and Global Capitalism. Chicago: Haymarket Books.

Nadasdy, Paul. 2003. Hunters and Bureaucrats: Power, Knowledge, and Aboriginal-State Relations in the Southwest Yukon. Vancouver, BC: UBC Press.

Nader, Laura. 2010. The three-cornered constellation: Magic, science, and religion revisited. Pp. 205-218 in Laura Nader, ed., The Energy Reader. Malden, MA: Wiley-Blackwell.

Newitz, Annalee. 2006. Pretend We're Dead: Capitalist Monsters in American Pop Culture. Durham, NC: Duke University Press.

Nikiforuk, Andrew. 2010. Tar Sands: Dirty Oil and the Future of a Continent. Vancouver, BC: Greystone Books.

Radin, Paul. 1975. The Trickster: A Study in American Indian Mythology. New York: Greenwood Press.

Sahlins, Marshall. 1972. Stone Age Economics. Hawthorn, NY: Aldine. 1999. What is anthropological enlightenment? Some lessons of the twentieth century. Annual Review of Anthropology 28:i-xxiii.

Schindler, David W. 2010. Tar sands need solid science. Nature 468(4723):499_ 501.

Tanner, Adrian. 1979. Bringing Home Animals: Religious Ideology and Mode of Production of the Mistassini Cree Hunters. St. John's, NL: Institute of Social and Economic Research, Memorial University of Newfoundland.

Taussig, Michael T. 1980. The Devil and Commodity Fetishism in South America. Chapel Hill, NC: University of North Carolina Press.

Timoney, Kevin P. and Peter Lee. 2009. Does the Alberta tar sands industry pollute? The scientific evidence. Open Conservation Biology Journal $3: 65-81$.

Valdivia, Gabriela. 2010. Petro-capitalism. In Green Politics: An A-to-Z Guide (online version), edited by Dustin Mulvaney. Thousand Oaks, CA: Sage.

Vincent, Sylvie. 1991. La présence des gens du large dans la version montagnaise de l'histoire. Anthropologie et Sociétés 15(1):125-143.

Waldram, James B. 2004. Revenge of the Windigo: The Construction of the Mind and Mental Health of North American Aboriginal Peoples. Toronto: University of Toronto Press.

Watts, Michael. 2006. The sinister political life of community: Economies of violence and governable spaces in the Niger Delta, Nigeria. Pp. 101-142 
in Gerald W. Creed, ed., The Seductions of Community. Santa Fe, NM: School of American Research Press.

Weismantel, Mary. 2001. Cholas and Pishtacos: Stories of Race and Sex in the Andes. Chicago: The University of Chicago Press.

Westman, Clinton N. 2006. Assessing the impacts of oilsands development on indigenous peoples in Alberta, Canada. Indigenous Affairs 2-3/06:30-39.

2008. Understanding Cree Religious Discourse. Ph.D. Thesis. Department of Anthropology, University of Alberta.

2010. The making of isolated communities in the Lesser Slave Lake interior, Alberta. Pp. 223-241 in M.A. Lindsay and M.A Richard, eds., Papers from the Rupert's Land Colloquium 2008. Winnipeg: Centre for Rupert's Land Studies, University of Winnipeg.

In Press. Oilsands development and Aboriginal people in Alberta, Canada: Impacts, processes, and responses. Accepted for translation in Terres (dés)humanisées: ressources et climat, edited by Charlotte Breda, Mélanie Chaplier, Julie Hermesse, and Emmanuelle Picolli, Investigations d'Anthropologie prospective (series), edited by Pierre-Joseph Laurent, Jacinthe Mazzocchetti, Olivier Servais, and Anne-Marie Vuillemenot. Louvain-la-Neuve, Belgique, and Paris, France: Academia/L'Harmattan.

Clinton Westman grew up in rural Alberta, received a Ph.D. in Sociocultural Anthropology from the University of Alberta, and was SSHRC Post-Doctoral Fellow in Anthropology at the University of Montreal. He is currently Assistant Professor in the Department of Archaeology and Anthropology, University of Saskatchewan. His research interests are in environmental anthropology and anthropology of religion. Recent publications include "Social Impact Assessment and the Anthropology of the Future in Canada's Tar Sands." (2013, Human Organization 72.2, 111-120). 
